doi: 10.52370/TISC21382ML

\title{
TOURISM POLICY CHALLENGES AMID COVID-19
}

\author{
Miljan Leković $^{1}$; Sonja Milutinović ${ }^{2}$
}

\begin{abstract}
The COVID-19 pandemic devastated tourist turnover and caused a crisis of unprecedented proportions in the tourism economy. The strong impact of the pandemic on the tourism sector requires even stronger response of tourism policy, whose primary task is to mitigate the negative effects of the pandemic and, firstly, to propose measures to support the current tourism sector, and then measures aimed at recovering this activity and increasing its flexibility and resistance to future challenges. In this regard, the aim of the paper is to emphasize the importance of effective and responsible tourism policy in crisis situations and point out the numerous challenges faced by tourism policy makers when defining measures to support the tourism economy. By applying qualitative economic analysis, it was concluded that there is no single solution, i.e. universal measures and universal packages of assistance to the tourism sector equally applicable and effective for all countries, but that each country, when creating tourism policy, should respect its own specifics and strive to create a package of measures that will generate the best results in the national framework.
\end{abstract}

Key Words: tourism policy, COVID-19 pandemic, health security, UNWTO recommendations

JEL classification: Z32, Z38

\section{Introduction}

The coronavirus pandemic is a global health crisis, which has resulted in a global economic crisis with the most severe disorders since World War II

\footnotetext{
${ }^{1}$ Miljan Leković, Ph.D, Assistant Professor, University of Kragujevac, Faculty of Hotel Management and Tourism in Vrnjačka Banja, Vojvođanska 5a, 36210 Vrnjačka Banja, Serbia, +381643582304, m.lekovic@kg.ac.rs

${ }^{2}$ Sonja Milutinović, Ph.D, Assistant Professor, University of Kragujevac, Faculty of Hotel Management and Tourism in Vrnjačka Banja, Vojvođanska 5a, 36210 Vrnjačka Banja, Serbia, +381648198998, sonja.milutinovic@kg.ac.rs
} 
(Gössling et al., 2021). The combined health and economic crisis has made a severe impact on modern society, questioning the health and economic security of the population. According to Hanić (2020), "the pandemic has completely changed the economic and social aspect of human civilization" (p. 9).

The first case of coronavirus infection was recorded in December 2019 in the Chinese city of Wuhan, and only a few months later, on $11^{\text {th }}$ March, 2020, the World Health Organization declared a pandemic, which speaks more than enough about the speed of virus transmission (Chen et al., 2020) and the fact that the global health, and soon the global economic system, faced a great challenge overnight.

The tourism industry has suffered a particularly strong impact and severe consequences caused by the COVID-19 pandemic, and especially the countries that, using abundant natural potentials and resources, base their economic development excessively on the tourism development ("Dutch disease") ${ }^{3}$. Numerous authors (Collins-Kreiner \& Ram, 2020; Strielkowski, 2021) agree that the pandemic had a devastating impact on tourism, causing several months of closure of this industry in 2020. Endangered health security of tourists, limited international travel, and often travel within national boundaries, contactless and remote provision of services and health protocols, or "life under masks" in general, have caused a sharp decline in tourist turnover. According to the analysis by the Pew Research Center (2020), as of $31^{\text {st }}$ March 2020, 91\% of the world's population has lived in countries completely or partially closed to non-residents. This had a strong negative implications for international tourism trends, which were almost globally disabled even a year later.

In short, the pandemic brought to the surface all the weaknesses of the tourism economy and indicates that in the period that follows, it is necessary to make tourism sector stronger, more resilient to shocks and generally more sustainable in crisis conditions. According to Gössling et al. (2021), "there is an urgent need not to return to business-as-usual when the crisis is over, rather than an opportunity to reconsider a transformation of the global tourism system more aligned to the SDGs (Sustainable Development Goals)" (p. 15). This can only be achieved through an efficient and consistent tourism policy.

\footnotetext{
3 "Dutch disease" is a term used in the relevant literature for the country's economy overreliance on a single resource and activity (Čavrak, 2020).
} 
In this regard, the subject of the paper are the challenges tourism policy is facing during the COVID-19 pandemic. The aim of the paper is to acquaint the academic society more closely with the role and importance of tourism policy, which is especially evident in times of crisis situations such as the current coronavirus pandemic. The motive for conducting the research results from the fact that there is a lack of studies in the domestic literature that deal with this issue. Due to the intention of the authors is to encourage future research in this subject area.

In order to achieve defined aim of the paper and draw valid conclusions concerning research subject, a qualitative research methodology based on the study of relevant and current literature in this field will be applied.

\section{The effect of the COVID-19 pandemic on tourism}

The effects of the COVID-19 pandemic on tourism have undoubtedly captured the attention of tourism researchers (Collins-Kreiner \& Ram, 2020; Gössling et al., 2021; Luković \& Stojković, 2020; Strielkowski, 2021; Škare et al., 2021), as evidenced by the dedication of numerous scientific conferences to this issue, but also special editions of the world's most influential scientific journals, whose focus is precisely the effect of the current crisis on the tourism industry. For example, in late 2020, the scientific journal Tourism Geographies published a special issue entitled "Visions of travel and tourism after the global COVID-19 transformation of 2020". It is not difficult to conclude that the academic society is trying to determine the consequences of the crisis, examine the causes of high tourism sensitivity, but also suggest steps and directions to mitigate the negative effects of the pandemic and increase the tourism sector resilience to future challenges.

Although in the new millennium tourism has shown satisfactory resilience during mild health crises of small scale (SARS, H1N1, MERS) and the global financial and economic crisis from the end of 2007, the current coronavirus pandemic has "brought this activity to its knees" and represents "an unprecedented crisis for the tourism economy" (OECD, 2020, p. 4). In many countries of the world, in the first half of 2020, an emergency situation of different time frames was declared, which prevented tourist movements and implied a complete closure ("lockdown") of the tourist market with unforeseeable consequences. In this way, a strong strike was dealt not only to international, but also to domestic tourism as the last 
refuge of tourist activity, which partially and in one period withstood the crisis.

The effect of the COVID-19 pandemic on the global tourism industry is best reflected in the following data (UNWTO, 2021; WTTC, 2021): 1) the number of international tourist arrivals in 2020, as the first year of the pandemic, decreased by 1.1 billion (drop of 74\%) compared to 2019 (1.5 billion visitors during 2019 compared to 381 million visitors during 2020), 2) the share of tourism in global gross domestic product (GDP) has decreased from $10.4 \%$ in 2019 to $5.5 \%$ in 2020 , 3) 62 million tourism employees lost their jobs during 2020 (the number of employees decreased from 334 million in 2019 to 272 million employees in 2020).

When it comes to individual tourist destinations, the pandemic certainly affected to a greater extent those which development strategies were focused on international tourism and which are predominantly visited by foreign tourists. Also, those destinations whose development is based on the concept and philosophy of mass tourism are affected to a greater extent. In this regard, Gössling et al. (2021) point out that "the COVID-19 crisis should be seen as an opportunity to critically reconsider tourisms growth trajectory, and to question the logic of more arrivals implying greater benefits" (p. 13).

Besides the fact that tourism is a labor-intensive activity (Milutinović \& Stanišić, 2019), it is also characterized by a pronounced fragmentation which is reflected in the business of a large number of small and medium enterprises which are more sensitive to crisis shocks compared to a large ones. If the pandemic lasts, many tourist companies will not survive despite state aid, which will result in a reduction in tourist capacity and further complicate the return of tourist turnover to the level that existed before the pandemic. In that sense, it is important to point out the importance of returning the trust not only of tourists, but also of investors, without whose capital it is not possible to renew the extinguished tourist capacities. Therefore, in the framework of tourism policy and planning, post-covid encouragement of investments in the tourism industry is highly recommended.

The most common types of struggle of tourist companies with the pandemic are drastic reduction of prices and promotion of high hygiene standards and health safety. Since young people on average have less aversion to all types of risks, including health risk, the promotional 
activities of tourism companies are increasingly aimed at the younger population, and are realized by applying all available modern means of communication. Reliable and accurate informing in order to reduce uncertainty is an important prerequisite for the return of tourist confidence and increase of tourist turnover in the near future.

At the time of the coronavirus pandemic, health care measures have no alternative. However, a special problem is reflected in the fact that mitigating the health crisis and implementing health measures, such as restricting movement, further deepen the economic crisis and, within it, the crisis of the tourism sector. The solution to the problem can be seen in the mass vaccination of the world's population, which would mark the end of the pandemic and create conditions for economic recovery, while "intermediate measures" only slow down the pandemic without indications of its end and global recovery. Additional uncertainty is generated by coronavirus mutations, which threaten to challenge the effectiveness of currently available vaccines and jeopardize the recovery of the world's population. According to Fotiadis et al. (2021), "without the medical solution to the pandemic, tourists will be reluctant to travel, despite the protective measures taken by transport and hospitality compaines" (p. 13).

Based on the above, it could be concluded that the duration and depth of the tourism economy crisis are predominantly determined by the duration of the current pandemic. Unfortunately, no pandemic can be stopped overnight, due to which the crisis in the tourism sector will certainly last and leave serious economic consequences, especially for those national economies that rely heavily on this activity. Even when the pandemic ends, the newly adopted health protocols will continue to slow tourism recovery. The fact that the tourist activity is extremely suitable for the spread of the virus is also the biggest obstacle to the rapid and complete recovery of this activity. For this reason, it can be expected that tourism will be one of the sectors with the slowest recovery.

Finally, in addition to numerous negative effects, it is possible to single out a couple of positive impacts of the pandemic on tourism, such as raising awareness of: 1) tourism policy makers about the importance of increasing resilience and flexibility of the tourism sector in crisis situations, 2) all tourism actors about the importance of respecting and further improving hygiene standards and health safety and 3) the importance of further application of modern information technologies and achieving a higher 
level of digitalization of tourism sector (virtual visit to galleries, museums, theme parks, cultural monuments).

\section{Challenges faced by tourism policy makers amid COVID-19 pandemic}

The current crisis of tourism sector, due to the speed of occurrence, devastating consequences and uncertainty in terms of duration, certainly represents a great challenge for tourism policy creators. The uncertainty of the crisis duration in the tourism economy arises from the uncertainty of the COVID-19 pandemic duration, as an external cause of the crisis that feeds and encourages it. Crisis situations result in the creation of a "vicious circle" from which individual companies, economic activities, economic sectors, national economies and the overall world economy find a way out with difficulty.

An efficient tourism policy is a precondition for tourism development, and the tourism development itself gives impulse to further improvement of tourism policy. The efficiency of tourism policy is achieved through meaningful, integrated and coordinated action of all its participants. Tourism policy should define short-term, medium-term and long-term development goals, specify a list of priorities, but also define instruments and measures for their implementation and operationalization.

According to Ubavić (2015), tourism policy "is part of the general economic policy and as such includes a set of measures and instruments of conscious state influence aimed at developing and improving tourism, raising and maintaining its competitiveness, and achieving a number of economic and non-economic goals of tourism development" (p. 20). In short, tourism policy is "the state's attitude towards tourism in a particular country" (Bartoluci, 2013, p. 237).

It is important to point out that the tourist activity originally functioned according to market laws (Stanišić \& Milutinović, 2016), without the influence and intervention of the state, which subsequently, after realizing the impact of tourism on the national economy, started the process of planning tourist activity. Since tourism policy is primarily focused on the tourism development, and indirectly on the overall economic development, its basic feature is the development feature (Bartoluci, 2013), where development must be based on the principles of sustainability (Ristić et al., 2016). 
Tourism policy does not have a universal character, but differs from country to country, trying to take into account the specifics of individual countries and their economies. Also, tourism policy is a dynamic category accessible to changes in time that occur due to changes in the circumstances in which tourist activity takes place. In short, the tourist thought and policy of an era should be appropriate to that era, given circumstances and specifics of a particular country and its tourism sector.

In crisis circumstances, in addition to tourism policy, which with its instruments and measures acts at the macro level, the indispensable role of crisis management stands out, which at the level of individual tourism companies should amortize crisis shocks, protect vital interests, ensure survival and propose the exit path and strategy of a specific tourist entity from the crisis. It is important to point out that the effectiveness of tourism policy and crisis management is hampered by numerous difficulties, among which some authors, such as Čavrak (2020), pointed out "cognitive gap and time gap of decision making and implementation" (p. 9).

Tourism policy and its creators faced a special challenge at the time of the current pandemic, which required prompt and efficient action. The precondition for formulating an effective and efficient tourism policy is deep understanding of the basic features of the crisis, the mechanisms through which it operates and the consequences it creates for the tourism sector. Due to the unpredictable future, tourism policy makers must be vigilant and strive for a solid foundation and improvement of tourism resilience and sustainability.

The usual response of tourism policy to crisis strikes is to take measures that will amortize the shock, then to take measures of financial support to the tourism sector, then to implement a strong marketing response to restore tourist confidence and restore the attractiveness of the tourist destination, and finally, to take preventive measures that will prevent or at least mitigate the negative effects of future crisis events.

In 2020, as the first year of the pandemic, the tourism policy of most countries in the world was aimed at taking short-term direct measures in the form of one-time state aid, primarily financial, to the tourism sector. In addition to the package of financial assistance to the overall economy, and thus to the tourism sector, which most often contained fiscal relief (tax exemptions, deferral of tax payments, suspension of compulsory social security contributions, abolition of tourist tax) and liquidity injections 
(grants, interest-free loans, credit lines, credit guarantees), tourist activity as one of the most affected and most endangered, often received special additional assistance and state support (payment of the minimum wage for employees in tourism, payment of special financial assistance to unemployed tourist workers, subsidizing insurance policies, special credit lines, introduction and legal regulation of "substitute" travel).

Obtaining financial support from the state was, among other things, conditioned by keeping existing workers employed. This condition refers especially to labor-intensive activities that include tourism, because the crisis of these activities can strongly affect the increase of one of the key macroeconomic problems - the problem of unemployment, which growth would nullify the positive effects of financial support.

It is important to point out that, unlike the "white" economy, the "gray" economy is left at the mercy of the crisis, i.e. without state support and assistance, which is understandable since it is under the radar of state bodies and does not contribute to the state budget. However, since the "gray" economy has a significant share in both global and individual national economies, the deep crisis of this economy segment, left out of the state support program, further deepens the overall economic crisis and hinders economic recovery. In this regard, some authors, such as Williams and Kayaoglu (2020), paid special attention to persons who were informally employed before the pandemic and who lost their income during the crisis, but also the opportunity to apply for state aid. Since the "gray" economy has a strong influence in seasonal activities such as tourism (Leković et al., 2020), tourism policy creators should pay special attention to this issue in the months ahead.

With the slowdown of the pandemic and the opening of countries announced for the second half of 2021, it is to be expected that the focus of tourism policy will shift from direct financial support to measures that will indirectly, but long-term affect the recovery of tourism sector and contribute to increasing its resilience and flexibility in crisis conditions. The backbone of the tourist activity recovery should be the recovery of domestic tourism, because the trust of tourists is gained faster in the national than in the international framework. Recovery can be achieved only through joint and coordinated action of all actors in the tourism industry at the national, regional and local levels. In addition to coordination, the precondition for a successful recovery is a gradual and 
balanced action, because a sudden opening and radical turns would be counterproductive.

In connection with the foregoing, in the first months of the post-covid period the destination is expected to rely more strongly on domestic tourism, which has shown greater resilience and flexibility and "kept alive" the tourism of many countries. At the same time, it should not be forgotten that domestic tourism is only one side of the tourist medal, which is why the complete recovery of tourism, in the true sense of the word, requires revival and accelerated multiplication of international tourist trips, return of foreign tourists and recovery of international tourism in general. Therefore, the initial post-covid tourism policy, and within it the tourism development strategy, should be focused not only on strengthening domestic tourism, but also on the targeted attraction of foreign tourists vaccinated against COVID-19 (virus-free tourists). In this regard, it is important to devise an internationally accepted way of proving the validity of foreign tourists' claims about the received vaccine. One of the solutions offered by the European Union whose introduction is announced are covid passports.

The introduction of covid passports is primarily advocated by those European Union member states that are highly dependent on tourism, such as Greece, Italy and Spain. However, at the same time, this solution opens up numerous problems, such as endangering the right to choose and discrimination against persons who have not been vaccinated. In addition to the introduction of covid passports, some authors, such as Strielkowski (2021), point out that the introduction of modern technological solutions such as smart tracing, health tracking bracelets and various useful applications that would help identify healthy, vaccinated and, in a word, risk-free passengers, should be considered.

Moreover, within the tourism policy framework, consideration should be given to selecting those segments of the fragmented tourism sector that are more strongly affected by the pandemic and allocating them greater financial aid and support. The negative effects of the pandemic are, for example, more pronounced in the case of luxury hotels, since most of their guests are foreign tourists. In addition to turnover drop, luxury hotels have also been hit by a sharp drop in stock value.

Also, in times of crisis, solidarity, empathy and joint action gain special significance and weight. Therefore, state support measures should be more 
generous in the case of those tourism companies that showed solidarity during the pandemic, such as hotels that ceded their accommodation facilities to care of sick people infected with coronavirus.

Finally, it should not be forgotten that, in addition to taking care of the visitors' (tourists') health safety, taking care of the tourist workers' health safety is equally important. By studying the relevant literature, one gets the impression that insufficient attention has been paid to this issue and that the safety of tourists is in the foreground. Health and tourism policy creators must not lose sight from the fact that virus-free tourism workers are a prerequisite for the existence of virus-free tourists. Virus-free tourism workers are at the same time a precondition for the tourism recovery, which is why they should certainly take one of the priority places on the scale of collective vaccination against COVID-19.

\section{Recommendations for mitigation and gradual exit from the crisis in the tourism economy}

In April 2020, the United Nations World Tourism Organization (UNWTO) instructed 23 recommendations to tourism policy makers around the world for mitigation and gradual exit from the crisis, grouped into three action strategies (UNWTO, 2020, pp. 11-13):

- managing the crisis and mitigating the impact: "1) incentivize job retention, sustain the self-employed and protect the most vulnerable groups; 2) support companies' liquidity; 3 ) review taxes, charges, levies and regulations impacting transport and tourism; 4) ensure consumer protection and confidence; 5) promote skills development, especially digital skills; 6) include tourism in national, regional and global economic emergency packages; 7) create crisis management mechanisms and strategies";

- providing stimulus and accelerating recovery: "8) provide financial stimulus for tourism investment and operations; 9) review taxes, charges and regulations impacting travel and tourism; 10) advance travel facilitation; 11) promote new jobs and skills development, particularly digital ones; 12) mainstream environmental sustainability in stimulus and recovery packages; 13) understand the market and act quickly to restore confidence and stimulate demand; 14) boost marketing, events and meetings; 15) invest in partnerships; 16) mainstream tourism in national, regional and international recovery programmes and in Development Assistance"; 
- preparing for the future: "17) diversify markets, products and services; 18) invest in market intelligence systems and digital transformation; 19) reinforce tourism governance at all levels; 20) prepare for crisis, build resilience and ensure tourism is part of national emergency mechanism and systems; 21) invest in human capital and talent development; 22) place sustainable tourism firmly on the national agenda; 23) transition to the circular economy and embrace the SDGs".

The question that logically arises from the previously listed recommendations is the question of their adoption by individual countries. This issue has captured the attention of authors Collins-Kreiner and Ram (2020) who, on the example of seven countries from different parts of the world, examined the degree of adoption of UNWTO recommendations. The research results showed that the first strategy "managing the crisis and mitigating the impact" was partially accepted, that the second strategy "providing stimulus and accelerating recovery" was adopted only to a lesser extent, while the third strategy "preparing for the future" was not adopted, given that only one in seven countries adopted one of the seven recommendations of the third strategy. Among the recommendations contained in the first strategy, the most widely accepted are: "incentivize job retention, sustain the self-employed and protect the most vulnerable groups" and "support companies' liquidity", within the second strategy: "review taxes, charges and regulations impacting travel and tourism" and "advance travel facilitation", while within the third strategy the only accepted recommendation (by only one country in the sample) is "invest in human capital and talent development".

The different adoption degree of the UNWTO recommendations is, among other things, the result of different reactions of individual countries to crisis situations. Different countries adopt UNWTO recommendations to different degrees, as their tourism sectors have been affected by the crisis to varying degrees and in different ways. Also, when creating a tourism policy, each country respects its own specifics and creates a package of measures that gives the best results within the national framework.

Earlier in the paper, it was emphasized that the pandemic and economic crisis particularly affected those countries that suffered from the "Dutch disease", i.e. which, using abundant natural potentials and resources, based their economic development excessively on the tourism development. A study conducted by Khalid et al. (2021) on the example of 136 countries shows that countries with a strong reliance on the tourism sector, aware of 
their vulnerability, reacted more decisively and extensively, implemented stronger measures and singled out a more generous package of economic assistance compared to other countries.

Also, if the epidemiological situation is under control in some neighboring countries, but not in other parts of the world, the executive authorities of individual countries do not rule out the possibility of creating a "travel bubble" within which tourist turnover will be allowed only between neighboring countries that have acquired the status of virus free destinations. The creation of a travel bubble is in the interest of both outbound tourists and inbound tourist companies. At the same time, this is important not only for tourism, but also for many other activities whose development has been slowed by the absence of cross-border cooperation.

Based on the above, it can be concluded that there are no universal measures and universal aid packages equally applicable and effective for all countries and all parts of the world. Despite the undeniably good intention of the UNWTO to help individual countries, their tourism sector and tourism in general, by proposing measures for mitigation and a gradual exit from the crisis, the conclusion is that "there is no single solution for all" (Collins-Kreiner \& Ram, 2020).

The tasks that are set in the post-covid period before the tourism policy creators, holders and subjects, but also before tourism companies and tourism workers are:

- to build a more resilient and flexible post-covid tourism economy,

- to invest more in health safety and ensure compliance with hygiene standards,

- to increase investment in digitalization and virtualization of tourism experiences,

- to provide timely, reliable and accurate information as a basis for the tourists' trust,

- to rebrand tourist destinations which are insufficiently attractive to domestic and foreign tourists,

- to promote, in some countries underused, and in the world popular tourist niches,

- to improve tourism offer, tourist infrastructure and the quality of the tourist service. 
Fulfilling these tasks is a challenge that can be overcome only by responsible tourism policy and joint and coordinated action of all relevant actors at the local, regional, national and global levels.

Finally, it should be noted that, starting from drastically changed circumstances and the need to improve the resilience and flexibility of the tourism sector, tourism policy makers around the world have recognized the importance of auditing and supplementing existing tourism development strategies. For example, Australia has started to develop a long-term strategy for tourism development - Tourism 2030, Estonia has developed a medium-term national strategy for tourism development for the period 2021-2024, Finland has supplemented the existing tourism development strategies 2019-2028 in the part 2020-2021, and countries such as Hungary, Ireland and Iceland have developed Tourism Recovery Plan (OECD, 2020). In the coming period, it is to be expected that, due to the strong impact of the pandemic on the tourism sector, most countries in the world will start revising and supplementing existing tourism development strategies, taking into account comparative advantages, local specifics and differences, therefore the development strategies will also differ between individual countries.

\section{Conclusion}

All crisis situations lead the tourism policy creators to think about the ways and methods of amortization of crisis strikes and recovery of tourism activity. The current pandemic is "an opportunity to rethink tourism for the future" (OECD, 2020, p. 2). It is important that the tourism policy creators are aware of the fact that after the pandemic, nothing will be the same, and especially the habits, expectations and behavior of tourists will change.

The focus of all tourism economy actors should be, first the return, and then maintaining the tourists' trust, primarily in terms of hygiene standards and health safety. This was, for example, recognized by the Portuguese Tourist Organization, which applies the approach and slogan "Clean and Safe" (Dupeyras et al., 2020). At the same time, it is important to restore the trust of the local community, which at first will not look favorably on the mass visits of tourists. The return of trust and goodwill of the local community is a precondition for the recovery and development of tourism of a specific destination. 
In addition, it is important that tourism policy makers learn lessons from the current crisis in which tourism finds itself, in order to complete this industry with the missing elements and make it more resilient to external shocks. Some authors, such as Prideaux et al. (2021), point out that the lessons learned during the current pandemic can serve to more successfully coping with climate change as a great challenge, whose culmination is a matter of time if the current practice of insufficient care for the environment and insufficient application of circular economy principles continues.

It is necessary to emphasize that, unfortunately, during the pandemic, numerous weaknesses of modern society "surfaced", such as inefficiency of the health system, lack of empathy and solidarity, insufficient expediency and determination in taking unpopular measures. The response of the European Union was especially disappointing, which for years and decades has declaratively "inherited" the equality and solidarity of the union members as the greatest value.

Of particular concern is the fact that the economic crisis, and within it the crisis of the tourism economy, will last longer than the health crisis, because achieving health security is only a starting point on the way to economic recovery and solving economic problems. The health crisis will end at some point, that is, health security will be achieved (by vaccinating the population or creating collective immunity), but the economic crisis and its consequences will have a prolonged duration.

The limitation of the paper is reflected in the fact that it has a more theoretical than research character, i.e. it provides insight into the challenges faced by tourism policy, but not into the effectiveness of newly adopted measures and instruments. In future research, the qualitative analysis conducted in this paper should be supplemented by an adequate quantitative analysis in order to determine the real effects and effectiveness of tourism policy in crisis situations.

\section{References}

1. Bartoluci, M. (2013). Upravljanje razvojem turizma i poduzetništva: Turistička politika, razvoj i poduzetništvo u turizmu [Tourism development and entrepreneurship: Tourism policy, development and tourism entrepreneurship], Školska knjiga, d.d., Zagreb. 
2. Chen, M.-H., Demir, E., García-Gómez, C. D., Zaremba, A. (2020). The impact of policy responses to COVID-19 on U.S. travel and leisure companies. Annals of Tourism Research Empirical Insights, Vol. 1, No. 1, 100003.

3. Collins-Kreiner, N., Ram, Y. (2020). National tourism strategies during the Covid-19 pandemic. Annals of Tourism Research, 103076.

4. Čavrak, V. (2020). Makroekonomija krize COVID-19 i kako pristupiti njenom rješavaju. EFZG working paper series No. 20-03, 1-19. https://hrcak.srce.hr/236781, (27 February 2021).

5. Dupeyras, A., Haxton, P., Stacey, J. (2020). The Covid-19 crisis and tourism: Response and recovery measures to support the tourism sector in OECD countries, https://www.g20-insights.org/policy_briefs/the-covid19-crisis-and-tourism-response-and-recovery-measures-to-support-thetourism-sector-in-oecd-countries/, (27 February 2021).

6. Fotiadis, A., Polyzos, S., Huan, T.-C. T. C. (2021). The good, the bad and the ugly on COVID-19 tourism recovery. Annals of Tourism Research, Vol. 87, 103117.

7. Gössling, S., Scott, D., Hall, C. M. (2021). Pandemics, tourism and global change: A rapid assessment of COVID-19. Journal of Sustainable Tourism, Vol. 29, No. 1, 1-20.

8. Hanić, A. (2020). Crni labud u svetskoj ekonomiji. In Mitić, P., Marjanović, D. (Eds.), Black swan in the world economy 2020 (pp. 9-28). Beograd, Srbija: Institut ekonomskih nauka.

9. Khalid, U., Okafor, L. E., Burzynska, K. (2021). Does the size of the tourism sector influence the economic policy response to the COVID-19 pandemic? Current Issues in Tourism, 1-20.

10. Leković, M., Cvijanović, D., Pantić, N., Stanišić, T. (2020). Evaluative bibliometric analysis of recent trends in rural tourism literature. Economics of Agriculture, Vol. 67, No. 4, 1265-1282.

11. Luković, S., Stojković, D. (2020). Covid-19 pandemic and global tourism. Hotel and Tourism Management, Vol. 8, No. 2, 79-87. 
12. Milutinović, S., Stanišić, T. (2019). Imapact of tourism on employment in Serbia and its main competitors. $4^{\text {th }}$ International Scientific Conference Tourism in Function of Development of the Republic of Serbia: Tourism as a Generator of Employment, Vrnjačka Banja, Serbia, 113-130.

13. OECD (2020). Tourim policy responses to the coronavirus (COVID19), https://read.oecd-ilibrary.org/view/?ref=124_124984-7uf8nm95se\& title=Covid-19_Tourism_Policy_Responses, (27 February 2021).

14. Pew Research Center (2020). More than nine-in-ten people worldwide live in countries with travel restrictions amid COVID-19, https://www.pewresearch.org/fact-tank/2020/04/01/more-than-nine-inten-people-worldwide-live-in-countries-with-travel-restrictions-amidcovid-19/, (27 February 2021).

15. Prideaux, B., Thompson, M., Pabel, A. (2020). Lessons from COVID19 can prepare global tourism for the economic transformation needed to combat climate change. Tourism Geographies, Vol. 22, No. 3, 667-678.

16. Ristić, L., Vujičić, M., Leković, M. (2016). Tourism as a factor of sustainable development of rural areas belonging to Rudnička Morava. Economics of Agriculture, Vol. 63, No. 2, 665-680.

17. Stanišić, T., Milutinović, S. (2016). Impact of tourism on basic macroeconomic indicators in the European Union and Serbia. $1^{s t}$ International Scientific Conference Tourism in Function of Development of the Republic of Serbia: Spa Tourism in Serbia and Experiences in other Countries, Vrnjačka Banja, Serbia, 67-82.

18. Strielkowski, W. (2021). International tourism and COVID-19: postpandemic recovery strategies, Zenodo.

19. Škare, M., Soriano, D. R., Porada-Rochoń, M. (2021). Impact of COVID-19 on the travel and tourism industry. Technological Forecasting and Social Change, Vol. 163, 120469.

20. Ubavić, P. (2015). Turistička politika i mogući pravci razvoja turizma $\mathrm{u}$ Srbiji [Tourism policy and possible directions of tourism development in Serbia]. Ekonomija, teorija i praksa, Vol. 8, No. 1, 16-31. 
21. UNWTO (2020). Supporting jobs and economies through travel \& tourism: A call for action to mitigate the socio-economic impact of COVID19 and accelerate recovery, https://webunwto.s3.eu-west1.amazonaws.com/s3fs-public/2020-04/COVID19_Recommendations_ English_1.pdf, (21 March 2021).

22. UNWTO (2021). UNWTO Tourism Data Dashboard, https://www.unwto.org/ unwto-tourism-dashboard, (2 April 2021).

23. Williams, C. C., Kayaoglu, A. (2020). COVID-19 and undeclared work: impacts and policy responses in Europe. The Service Industries Journal, Vol. 40, No. 13-14, 914-931.

24. World Travel \& Tourism Council (WTTC) (2021). Economic Impact Reports, https://wttc.org/Research/Economic-Impact, (2 April 2021). 